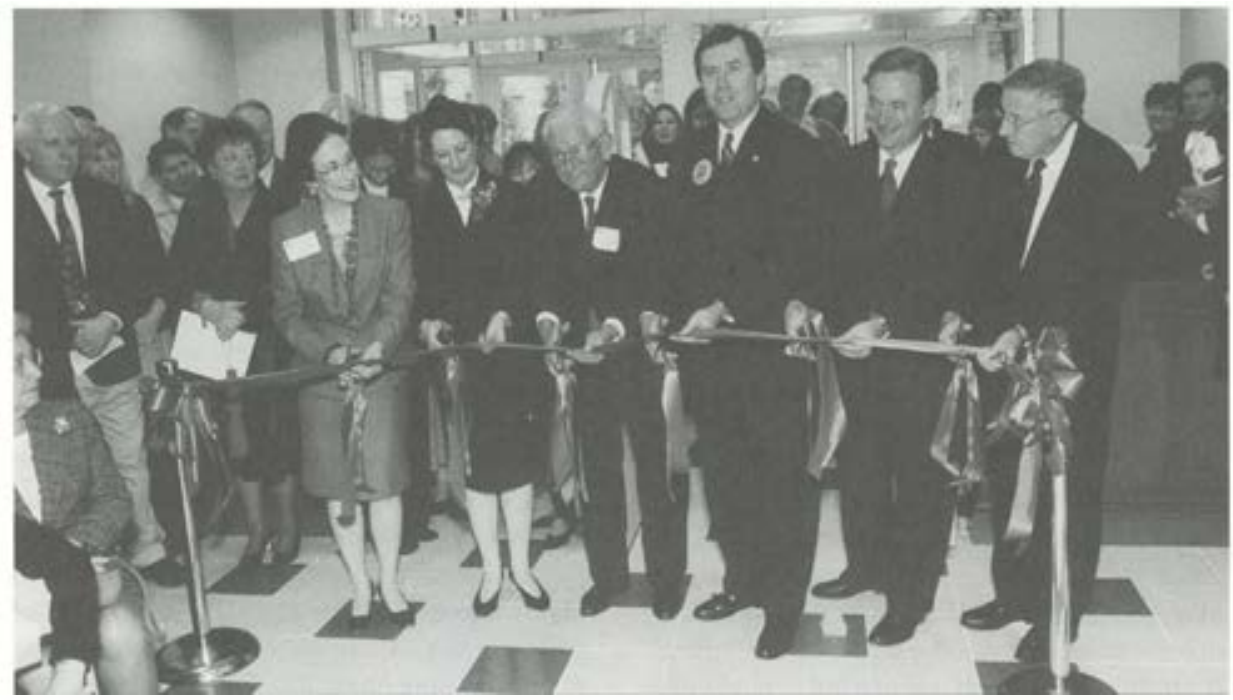

Southem Methodist University (SMU) opened its new Fondren Library Center recently as donors and university representatives stood poised to cut the ribbon. The complex encompasses the Fondren Library, the Science and Engineering Library, and the new 7,100 square foot building that will connect the two libraries. Pictured here are from right: SMU trustee and Fondren family representative Sue Irammel Whitfield; SMU Central University Librarian Gillian McCombs; Charles Selecman, grandson of Charles S. Selecman for whom the new Center's Selecman Tower is named; SMU President R. Gerald Turner; SMU Provost Ross Murfin; and library executive board member James Glasscock, who gave the invocation.

\title{
Support Library Legislative Day!
}

This year marks the 25 th anniversary of $\mathrm{Na}$ tional Library Legislative Day to be held in Washington, D.C. on May 3-4, 1999. These two days are of significant consequence to librarians in general-and academic librarians in particular - because they provide a venue for librarians to make acquaintance with their congressional representatives and to explain how their actions and policy decisions can affect your library. Considering the rapid changes that are occurring in our libraries due to evolving information technology, we must keep our representatives informed and educated more than ever concerning the implications of information policy on academic libraries.

On the first day, Monday, you will be briefed on general legislative issues important to libraries such as copyright, government information dissemination, appropriations, education funding, and discounted telecom rates. Also on Monday, ACRL will sponsor an activity designed to brief you on issues particularly important to academic librarians.
You may caucus with your state delegation later in the day. On Tuesday, you will join your state delegation and visit your congressional representatives, delivering your messages about library issues. Past experience of other academic librarians indicates that you may want arrive in D.C. on Sunday to be ready for the full day of activities on Monday.

The registration fee for Legislative Day is \$8. ALA has set aside a block of rooms at the Holiday Inn on The Hill [ 415 New Jersey Ave., N. W. phone: (202) 638-1616] at a special rate; ask for the ALA Rate of \$129 (single) and $\$ 139$ (double).

For more information and a registration form access the Legislative Day Web site at http://www.ala.org/washoff/legday.html. Check with your state association legislative committee about teaming with them for visits to the congressional offices.

If you plan to attend please let Michael Godow know.-Michael Godow, ACRL programofficer, mgodow@ala.ory. 